\title{
Geology
}

\section{Biomarkers heat up during earthquakes: New evidence of seismic slip in the rock record}

\author{
Heather M. Savage, Pratigya J. Polissar, Rachel Sheppard, Christie D. Rowe and Emily E. Brodsky
}

Geology published online 6 January 2014;

doi: 10.1130/G34901.1

\section{Email alerting services}

Subscribe

Permission request click www.gsapubs.org/cgi/alerts to receive free e-mail alerts when new articles cite this article

click www.gsapubs.org/subscriptions/ to subscribe to Geology

click http://www.geosociety.org/pubs/copyrt.htm\#gsa to contact GSA

Copyright not claimed on content prepared wholly by U.S. government employees within scope of their employment. Individual scientists are hereby granted permission, without fees or further requests to GSA, to use a single figure, a single table, and/or a brief paragraph of text in subsequent works and to make unlimited copies of items in GSA's journals for noncommercial use in classrooms to further education and science. This file may not be posted to any Web site, but authors may post the abstracts only of their articles on their own or their organization's Web site providing the posting includes a reference to the article's full citation. GSA provides this and other forums for the presentation of diverse opinions and positions by scientists worldwide, regardless of their race, citizenship, gender, religion, or political viewpoint. Opinions presented in this publication do not reflect official positions of the Society.

\section{Notes}

Advance online articles have been peer reviewed and accepted for publication but have not yet appeared in the paper journal (edited, typeset versions may be posted when available prior to final publication). Advance online articles are citable and establish publication priority; they are indexed by GeoRef from initial publication. Citations to Advance online articles must include the digital object identifier (DOIs) and date of initial publication.

(C) Geological Society of America

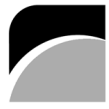

THE GEOLOGICAL SOCIETY 


\title{
Biomarkers heat up during earthquakes: New evidence of seismic
} slip in the rock record

\author{
Heather M. Savage ${ }^{1}$, Pratigya J. Polissar ${ }^{1}$, Rachel Sheppard ${ }^{1}$, Christie D. Rowe ${ }^{2}$, and Emily E. Brodsky ${ }^{3}$ \\ 'Lamont-Doherty Earth Observatory, Columbia University, Palisades, New York 10964, USA \\ 2Department of Earth and Planetary Sciences, McGill University, 3450 University Street, Montréal, H3A 0E8 Quebec, Canada \\ ${ }^{3}$ Department of Earth and Planetary Sciences, University of California-Santa Cruz,1156 High Street, Santa Cruz, California 95064, USA
}

\begin{abstract}
During earthquakes, faults heat up due to frictional work. However, evidence of heating from paleoearthquakes along exhumed faults remains scarce. Here we describe a method using thermal maturation of organic molecules in sedimentary rock to determine whether a fault has experienced differential heating compared to surrounding rocks. We demonstrate the utility of this method on an ancient, pseudotachylyte-hosting megathrust at Pasagshak Point, Alaska. Measurements of the ratio of thermally stable to thermally unstable compounds (diamondoids $/ n$-alkanes) show that the melt-bearing rocks have higher thermal maturity than surrounding rocks. Furthermore, the mineralogy of the survivor grains and the presence of any organic molecules allow us to constrain the temperature rise during the ancient earthquakes to 840-1170 ${ }^{\circ} \mathrm{C}$ above ambient temperatures of $\sim 260{ }^{\circ} \mathrm{C}$. From this temperature rise, we estimate that the frictional work of the earthquake was $\sim 105-228 \mathrm{MJ} / \mathrm{m}^{2}$. Using experimental friction measurements as a constraint, we estimate that the minimum slip necessary for heating was $\sim 1-8 \mathrm{~m}$. This paper demonstrates that biomarkers will be a useful tool to identify seismic slip along faults without frictional melt.
\end{abstract}

\section{INTRODUCTION}

The rock record is rich in fault structural detail, but independent identification of earthquakes is essential to relate these observations to earthquake processes. One of the only ways to identify earthquakes in outcrop is to measure the frictional heating on faults relative to the surrounding rock. However, frictional heating signatures in the rock record have proven elusive. Solidified frictional melt (pseudotachylyte) is the most accepted evidence of past earthquakes (Cowan, 1999) but is somewhat rare. Pseudotachylyte is especially rare in sedimentary rocks, even though most of the planet's great earthquakes occur within subducted sediments (e.g., Bjørnerud, 2009; Kirkpatrick and Rowe, 2013; Sibson and Toy, 2006). Recently developed alternative approaches to detect fault heating include trace element partitioning, thermal decarbonation, dehydration reactions, and vitrinite reflectance (e.g., Hamada et al., 2009; Han et al., 2007; Ishikawa et al., 2008; Sakaguchi et al., 2011). Here, we present a method that utilizes the thermal maturity of extractable organic material (biomarkers) to estimate the maximum frictional heating experienced by the fault (Peters et al., 2005; Polissar et al., 2011). Biomarker thermal maturity measures the same alteration of organic material as vitrinite reflectance. However, vitrinite reflectance is only measurable in sediments containing woody particles, and may be enhanced by total strain (Mastalerz et al., 1993). Furthermore, biomarkers are more commonplace than both vitrinite and pseudotachylyte in sedimentary rocks.

\section{Biomarker Thermal Maturity}

Organic matter from plants, algae, and bacteria is preserved in sediments. Subsequent burial systematic changes in its structure, bulk composition, and molecular geochemistry. Thermal maturity is revealed by transformation or destruction of less-stable versus more-stable compounds. Like any metamorphism, the extent of the reaction is dependent on both the reaction time and temperature. A variety of biomarker indices have long been used by the petroleum industry to estimate burial time-temperature regimes (Peters et al., 2005); here we repurpose these indices to measure much higher temperatures at very short time scales. In addition to the molecular composition, we also use the survival of any organic molecules as a constraint on the maximum temperature rise experienced by a fault.

Polissar et al. (2011) showed the absence of thermal maturity anomalies along multiple plate boundary faults, explained by low total coseismic slip, low coseismic friction, or a thick active slip zone during earthquakes. Here, we test our method on one of the few known pseudotachylyte-bearing faults hosted in sedimentary rocks, the Pasagshak Point megathrust at Kodiak, Alaska. Because significant frictional heating is known to have occurred, we demonstrate the efficacy of the biomarker method, and add new temperature constraints to a well-studied fossil earthquake that allow us to estimate frictional work and earthquake magnitude.

\section{Pasagshak Point Megathrust}

The Pasagshak Point megathrust is the preserved plate boundary fault from Paleocene subduction along the Alaska margin. The megathrust is composed of 7-31-m-thick anastomosing cataclastic shear zones that cut trench sediment and faulting heats this organic matter, leading to mélange (Rowe et al., 2011). Fossil earthquake layers are continuous along strike for $\sim 2.5 \mathrm{~km}$ and are composed of cataclastically deformed and melted metasediments (Meneghini et al., 2010; Rowe et al., 2005). The solidified frictional melts found in this location are among the thickest and most continuous found to date $(\sim 3-$ $20 \mathrm{~cm}$ ). These "black fault rocks" (BFRs) contain sub-millimeter-scale flow bands of pseudotachylyte and unmelted grains (ultracataclasite) that allowed for the heating, but incomplete destruction, of organic matter. Flow folding of the pseudotachylyte indicates that, at most, two events formed the BFRs (Rowe et al., 2011). Clasts of pseudotachylyte from veins that have subsequently been destroyed by earthquakes are present in the cataclasite layers (Rowe et al., 2011), further indicating that the pseudotachylyte layer studied here is most likely from a single event. The fault was active at $12-14 \mathrm{~km}$ depth (Vrolijk et al., 1988) and $260{ }^{\circ} \mathrm{C}$ burial temperature (Rowe et al., 2011). In this study, we analyzed samples from the BFRs and adjacent cataclasites in the megathrust. We also collected samples from outside the megathrust, to establish background maturity due to burial. The sediments metamorphosed at peak burial temperatures to quartz + albite + chlorite + illite \pm pyrite. Based on structural relationships, metamorphic mineralogy, illite crystallinity, and vitrinite reflectance, Rowe et al. (2011) concluded that the fault was at peak burial conditions when the BFRs formed. The fault became inactive by underplating to the accretionary wedge during the early Paleocene and there is no evidence for subsequent fault slip or increased burial.

Because of the background level of thermal maturity at Pasagshak Point, the most abundant organic molecules are diamondoids and shortchain alkanes. Diamondoids are hydrocarbons with a diamond-like ring structure that is highly stable, even at temperatures high enough to break down the surrounding petroleum molecules. As the temperature rises, diamondoids become more concentrated within the diminishing petroleum (Dahl et al., 1999; Wei et al., 2006). $n$-alkanes are linear, saturated hydrocarbons that are an important component of petroleum. Here we use $n$-alkane abundance to quantify the petroleum cracking reactions that concentrate diamondoid molecules. Organic thermal maturity reactions are not retrograde, therefore the measurements made here 

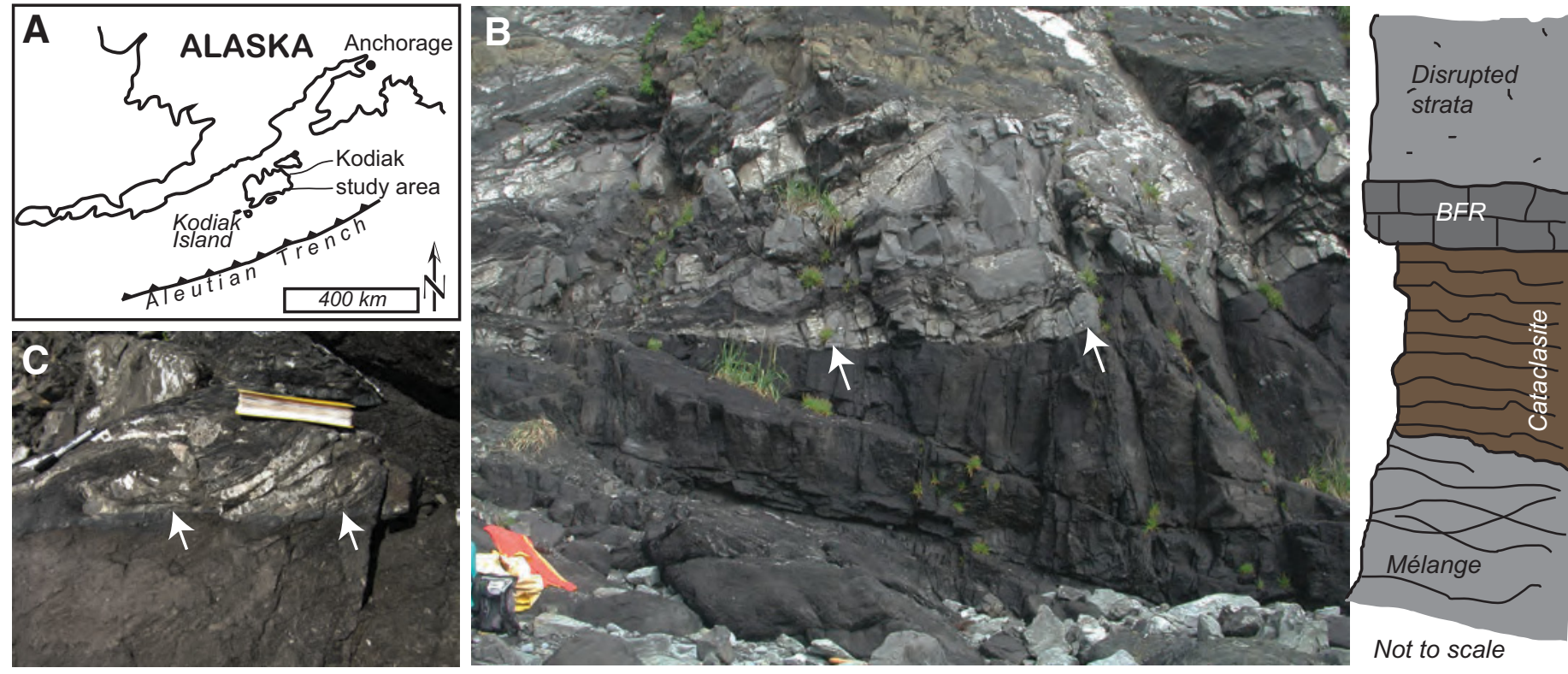

Figure 1. A: Location of Pasagshak Point megathrust on Kodiak Island, Alaska, USA. B: Samples were collected from several outcrops of paleo-earthquake slip surface (white arrows) that contained massive pseudotachylytes within cataclasite. Inset shows structure of fault zone. C: Black fault rock (BFR) containing pseudotachylyte (white arrows) occurs on discrete slip surfaces 3-20 cm thick along boundary between cataclasite (below) and disrupted strata of wall rock (above).

represent the maximum temperature achieved by the fault during the earthquake.

\section{METHODS}

Samples were collected from beach outcrops of the Pasagshak Point thrust (Fig. 1; Meneghini et al., 2010; Rowe et al., 2011). We analyzed samples of BFRs, cataclasites, and off-fault wall rock up to $200 \mathrm{~m}$ away from the megathrust (Fig. 1). The BFR samples include the thickest melt layers, as well as a sample of a thin BFR vein from within cataclasite. Subsamples of the thin BFR veins were cut with a rock saw from larger hand samples to isolate layers of veins and immediately adjacent cataclasite. All of the samples were then prepared and extracted, and molecules quantified using gas chromatography-mass spectrometry (GC-MS) (see the GSA Data Repository ${ }^{1}$ for analytical details and full sample description). We used the sums of diamantane (D) plus 1-, 3-, and 4-methyl diamantane (1MD, 3MD, 4MD) and the $\mathrm{C}_{10+} n$-alkanes to calculate the thermal maturity ratio:

$$
\begin{gathered}
(\mathrm{D}+4 \mathrm{MD}+1 \mathrm{MD}+3 \mathrm{MD}) \\
/\left(\sum \mathrm{C}_{10-40} n \text {-alkanes }\right),
\end{gathered}
$$

(our results are insensitive to which diamantane isomers are used in the calculation). In

${ }^{1}$ GSA Data Repository item 2014028, methods, calculation of the latent heat of melting, Figure DR1 (example of a chromatogram) and Table DR1 (detailed description of samples), is available online at www.geosociety.org/pubs/ft2014.htm, or on request from editing@geosociety.org or Documents Secretary, GSA, P.O. Box 9140, Boulder, CO 80301, USA. this ratio, $n$-alkane abundance characterizes total petroleum concentration, as we were unable to gravimetrically quantify total petroleum in these highly mature, low-concentration samples. Consistent with the high background maturity, $n$-alkane distributions were dominated by short-chain alkanes with a maximum abundance at $\mathrm{C}_{16}-\mathrm{C}_{18}$ carbon chain lengths and an average chain length of $\sim 17$, indicating significant prior cracking of longerchain-length $n$-alkanes.

\section{BIOMARKER ALTERATION}

The ratio of diamondoids to $n$-alkanes increases with proximity to the BFRs (Fig. 2). The samples of the BFRs are the most thermally mature. The cataclasite sample that was carefully removed from next to the BFR vein (Fig. 1C) is less thermally mature than the BFRs and slightly more thermally mature than the cataclasites that were further from BFRs. Samples from outside of the megathrust showed the lowest thermal maturity, displaying the background burial temperature. Although the cataclasites were much less mature than the BFRs, they are more mature than the background samples, indicating some degree of frictional heating in the cataclasites or heat conduction from the BFRs. Although we cannot rule out hydrothermal fluid flow, there is no evidence of veining contemporaneous with fault deformation. Furthermore, heating from hydrothermal fluids would result in the opposite pattern of maturity because fluid flow would be concentrated in the more permeable damage zone rather than the low-permeability fault gouge.
Our results are the first geologic evidence that biomarkers react to rapid heating due to earthquakes (earthquake slip at a particular spot on a fault lasts on the order of seconds). To date, our knowledge of temperature rise along faults has been mostly limited to the extreme case of melting. This method allows us to examine faults that have experienced low to intermediate temperature rise.

The discovery that organic compounds can react at earthquake time scales opens up a new tool for detection of fault slip in any fault that cuts sedimentary rocks. This method does not work in crystalline rocks, nor sedimentary rocks that have been metamorphosed to the

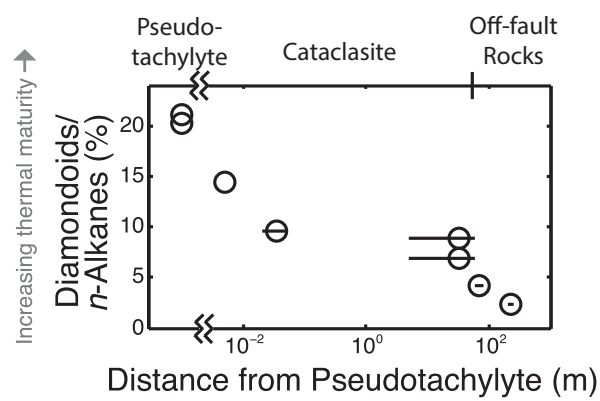

Figure 2. Thermal maturity of Pasagshak Point (Kodiak Island, Alaska) fault rocks as determined by ratio of diamandoids to $n$-alkanes. Samples within pseudotachylyte have greatest thermal maturity; thermal maturity decreases with distance from pseudotachylyte layers. Horizontal lines represent uncertainty in distance from a pseudotachylyte layer for certain samples. 
degree that all hydrocarbons are destroyed. To detect frictional heating, our method requires that the fault and the surrounding rock had the same hydrocarbon populations before the slip event(s), e.g., that the fault rocks have not been exposed to preferential hydrocarbon flow. Evidence indicating that these conditions are met at Pasagshak Point includes: (1) a background thermal maturity consistent with the geologically constrained burial depths and previous temperature estimates, (2) low concentrations of organic matter in the rocks (petroleum migration is likely to leave higher concentrations of organic material behind), and (3) likely petroleum sources would come from depth, have a higher thermal maturity, and might flow through the highest-porosity rocks-not the low-porosity pseudotachylytes, which we found to have the highest thermal maturity.

At present we can use the changes in diamondoid $/ n$-alkane molecules to indicate relative levels of heating. Absolute temperatures will require determination of reaction kinetics with short-duration high-temperature experiments $\left(10^{\circ}-10^{2} \mathrm{~s}, 1000-1500{ }^{\circ} \mathrm{C}\right)$. The currently available experiments at lower temperatures and longer time scales do not directly scale to the rapid heating at very high temperatures, and suggest total destruction of these compounds at Pasagshak Point temperatures (Waples, 2000; Wei et al., 2006), contrary to what we observed. While future experiments can provide kinetic parameters that allow determinations of absolute temperatures, our current results allow us to document relative levels of thermal alteration in relation to frictional melting, cataclasis, and burial heating.

\section{TEMPERATURE RISE AT PASAGSHAK POINT}

Although the kinetics of diamondoids have to date not been calibrated to seismic temperatures and heating times, we can put a temperature bound on the preserved earthquake rocks. The preferential melting of albite relative to quartz (Rowe et al., 2005) indicates that the temperature was most likely above $1100{ }^{\circ} \mathrm{C}$ (Spray, 2010). The observation of melted albite is found across the entire pseudotachylyte-bearing layer; there is no gradation or other evidence that peak temperature was not reached everywhere within it. An upper limit on the temperature can be estimated from the conditions at which hydrocarbons pyrolytically decompose. Methane is a product of pyrolysis of larger $n$-alkanes, therefore the detection of $n$-alkanes in the BFR indicates a temperature less than required for the destruction of methane. At temperatures above $1430{ }^{\circ} \mathrm{C}$, methane is found to quantitatively decompose to $\mathrm{H}_{2}$ and $\mathrm{C}$ after $\sim 0.3 \mathrm{~s}$ in the gas phase at atmospheric pressure (Burgoyne and Hayes, 1998; Arutyunov et al., 1991). This estimate provides an upper bound on temperature because (1) pyrolysis of $n$-alkanes detected in the BFR occurs at lower temperatures than that of methane (Tilicheev, 1949; Voge and Good, 1949), thus requiring temperatures below $1430{ }^{\circ} \mathrm{C}$; (2) methane decomposition rates are faster at higher pressures (Barnes et al., 1989), such as the $200 \mathrm{MPa}$ from the burial depth; and (3) the heating duration was probably longer than $0.3 \mathrm{~s}$, thus lower temperatures would cause similar levels of destruction (Arutyunov et al., 1991). Therefore, peak temperature in the Pasagshak Point slip surface was $\sim 1100-1430{ }^{\circ} \mathrm{C}$. The burial temperature for this fault has been estimated as $260{ }^{\circ} \mathrm{C}$ (Rowe et al., 2011), consequently the estimated temperature rise is $\sim 840$ $1170{ }^{\circ} \mathrm{C}$. Previous studies of pseudotachylyte estimate a temperature rise of $750-1450{ }^{\circ} \mathrm{C}$ (Spray, 2010). The additional constraint of surviving organic molecules allows us to better estimate temperature rise than the presence of pseudotachylyte alone.

\section{ESTIMATES OF FRICTIONAL WORK}

Given the constraints on temperature and slip zone thickness at the Pasagshak Point megathrust, we can estimate the earthquake parameters for the event that generated such unusually large pseudotachylytes. Although the thicknesses of the pseudotachylyte layers vary between 3 and $20 \mathrm{~cm}$, we estimate that the minimum melt thickness is $3-5 \mathrm{~cm}$ when the volume of unmelted grains is taken into account (Rowe et al., 2011). The frictional work per area, $W_{\mathrm{f}}$, done on the fault is partitioned between the temperature rise $(\Delta T)$ along a fault and the latent heat (e.g., Pittarello et al., 2008):

$$
W_{\mathrm{f}}=\left(\Delta T c_{\mathrm{p}}+H\right) \rho h,
$$

where $h$ is fault thickness, $\rho$ is rock density, $c_{\mathrm{p}}$ is heat capacity of the rock, and $H$ is latent heat of melting. Using the temperature bounds from this study, the field observations, and standard material properties (Table 1), we find that the frictional work per area is $\sim 105-228$ $\mathrm{MJ} / \mathrm{m}^{2}$. Frictional heat dissipation here is significant. Previous estimates of frictional work include small faults in African gold mines (2-10 $\mathrm{MJ} / \mathrm{m}^{2}$; Reches and Dewers, 2005) and pseudotachylyte-bearing faults in Adamello, Italy, that had $\sim 1 \mathrm{~m}$ slip events $\left(27 \mathrm{MJ} / \mathrm{m}^{2}\right.$; Pittarello et al., 2008). Additionally, our estimate is much larger than measurements of fracture energy ( 10-20 MJ; Ma et al., 2006; Tinti et al., 2005), indicating that most energy from this earthquake was dissipated as heat.

Frictional work is the integral of the shear stress on the fault during slip. Therefore, we can use independent constraints on the shear stress to bound the slip on this fault during the pseudotachylyte-forming earthquakes. Based on the field observations, we infer that the normal stress on the fault is equal to overburden stress because active subduction margins dip $<10^{\circ}$, and that hydrostatic conditions exist on the fault (there are no veins or other evidence of suprahydrostatic pore pressures). Laboratory experiments on Pasagshak Point cataclasites confine the steady-state low-velocity $(\mu \mathrm{m} / \mathrm{s})$ coefficient of friction to $\sim 0.35-0.45$ (Marone et al., 2005) and high-velocity $(\sim 1 \mathrm{~m} / \mathrm{s})$ coefficient of friction to 0.15 ; however, the high-velocity experiments were performed at low normal stress (Tsutsumi et al., 2008). Because of this range in laboratory values, we consider a range of plausible values of the friction coefficient from 0.15 to 0.45 and normal stresses from $\sim 194$ to $226 \mathrm{MPa}$ (overburden stress minus hydrostatic pore pressure). With this constraint on shear stress, we estimate the total slip during the earthquake that contributed to temperature rise at Pasagshak Point to be between $\sim 1$ and $8 \mathrm{~m}$ (Fig. 3). Given the typical range of average stress drop for interplate faults (1-10 MPa), this slip corresponds to $\mathrm{a}_{\mathrm{w}}$ 6-8 earthquake (Hanks and Kanamori, 1979; Kanamori and Anderson, 1975). Note that these slips and magnitudes correspond to the dissipative portion of the slip history and do not reflect the entire slip. Once a continuous layer of melt is present, shear stress resolved on faults can drop precipitously to near zero (Brodsky et al., 2009) and further slip contributes little toward heating. Therefore, the slips reported are lowerbound estimates.

\section{CONCLUSIONS}

We demonstrate that biomarker thermal maturity can be used as a fault zone thermometer, in a fault known to have produced significant frictional heating during rapid earthquake slip. This method provides a way to determine temperature rise due to frictional heating in fault

TABLE 1. PARAMETERS FOR FRICTIONAL WORK AND DISPLACEMENT ESTIMATES

\begin{tabular}{|c|c|c|c|c|c|c|c|}
\hline $\begin{array}{l}\text { Temperature } \\
\text { rise }\left({ }^{\circ} \mathrm{C}\right)\end{array}$ & $\begin{array}{l}\text { Heat capacity } \\
\left(\mathrm{J} / \mathrm{K}^{\star} \mathrm{kg}\right)\end{array}$ & $\begin{array}{l}\text { Rock density } \\
\qquad\left(\mathrm{kg} / \mathrm{m}^{3}\right)\end{array}$ & $\begin{array}{l}\text { Water density } \\
\left(\mathrm{kg} / \mathrm{m}^{3}\right)\end{array}$ & $\begin{array}{l}\text { Fault thickness } \\
\text { (m) }\end{array}$ & $\begin{array}{l}\text { Depth of faulting } \\
(\mathbf{k m})\end{array}$ & $\begin{array}{l}\text { Latent heat of fusion* } \\
\qquad(\mathrm{MJ} / \mathrm{kg})\end{array}$ & $\begin{array}{l}\text { Friction } \\
\text { coefficient }\end{array}$ \\
\hline $840-1170$ & 1200 & 2650 & 1000 & $0.03-0.05$ & $12-14$ & 0.318 & $0.15-0.45$ \\
\hline
\end{tabular}




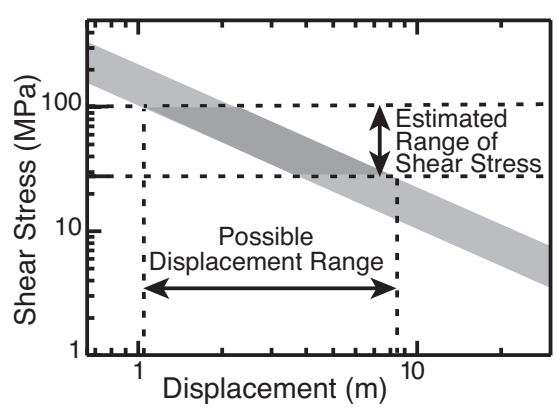

Figure 3. Values for shear stress and fault slip that could generate temperature rise observed in Pasagshak Point megathrust (Kodiak Island, Alaska). Gray bar represents acceptable range of work per area given constraints from mineralogy, presence of organic material, and fault zone thickness. Estimated range of shear stress is constrained by overburden stress, with hydrostatic pore pressures and friction determined from experiments.

zones where no other thermal indicators, such as pseudotachylyte, are present. Even when pseudotachylyte is present, as in the case of the Pasagshak Point megathrust, biomarkers provide an added constraint on temperature rise that allows for an estimation of earthquake magnitude and frictional work.

\section{ACKNOWLEDGMENTS}

We would like to thank J.C. Moore for help in sample selection. C. Scholz and N. van der Elst gave insightful comments on early versions of the manuscript. The paper was much improved from reviews by R. Han, G. Di Toro, M. Ikari, and an anonymous reviewer, as well as editor R. Holdsworth. This work was supported in part by National Science Foundation (NSF) grant EAR-0948740. Fieldwork was supported by NSF grant OCE-0203664 to J.C. Moore.

\section{REFERENCES CITED}

Arutyunov, V.S., Vedeneev, V.I., Moshikina, R.I., and Ushakov, V.A., 1991, Pyrolysis of methane under static conditions at 1100-1400 K: Kinetics and Catalysis, v. 32, p. 234-240.

Barnes, R.W., Pratt, G.L., and Wood, S.W., 1989, Pressure dependence of methane dissociation: Journal of the Chemical Society, Faraday Transactions 2: Molecular and Chemical Physics, v. 85, p. 229-238, doi:10.1039/F29898500229.

Bjørnerud, M., 2009, Rethinking conditions necessary for pseudotachylyte formation: Observations from the Otago schists, South Island, New Zealand: Tectonophysics, v. 490, p. 69 80, doi:10.1016/j.tecto.2010.04.028

Brodsky, E.E., Rowe, C.D., Meneghini, F., and Moore, J.C., 2009, A geological fingerprint of low-viscosity fault fluids mobilized during an earthquake: Journal of Geophysical Research, v. 114, B01303, doi:10.1029/2008JB005633.

Burgoyne, T.W., and Hayes, J.M., 1998, Quantitative production of $\mathrm{H}_{2}$ by pyrolysis of gas chromatographic effluents: Analytical Chemistry, v. 70, p. 5136-5141, doi:10.1021/ac980248v.

Cowan, D.S., 1999, Do faults preserve a record of seismic slip? A field geologist's opinion: Journal of Structural Geology, v. 21, p. 995-1001, doi:10.1016/S0191-8141(99)00046-2.
Dahl, J.E., Moldowan, J.M., Peters, K.E., Claypool, G.E., Rooney, M.A., Michael, G.E., Mello, M.R., and Kohnen, M.L., 1999, Diamondoid hydrocarbons as indicators of natural oil cracking: Nature, v. 399, p. 54-57, doi:10.1038/19953.

Hamada, Y., Hirono, T., Tanikawa, W., Soh, W., and Song, S.-R., 2009, Energy taken up by co-seismic chemical reactions during a large earthquake: An example from the 1999 Taiwan ChiChi earthquake: Geophysical Research Letters, v. 36, L06301, doi:10.1029/2008GL036772.

Han, R., Shimamoto, T., Ando, J.-i., and Ree, J.-H., 2007, Seismic slip record in carbonate-bearing fault zones: An insight from high-velocity friction experiments on siderite gouge: Geology, v. 35, p. 1131-1134, doi:10.1130/G24106A.1.

Hanks, T.C., and Kanamori, H., 1979, A moment magnitude scale: Journal of Geophysical Research, v. 84 , p. $2348-2350$, doi:10.1029 /JB084iB05p02348.

Ishikawa, T., and 12 others, 2008, Coseismic fluidrock interactions at high temperatures in the Chelungpu fault: Nature Geoscience, v. 1, p. 679-683, doi:10.1038/ngeo308.

Kanamori, H., and Anderson, D.L., 1975, Theoretical basis of some empirical relations in seismology: Bulletin of the Seismological Society of America, v. 65, p. 1073-1095.

Kirkpatrick, J.D., and Rowe, C.D., 2013, Disappearing ink: How pseudotachylytes are lost from the rock record: Journal of Structural Geology, v. 52, p. $183-198$, doi:10.1016/j.jsg.2013 .03 .003 .

Ma, K.-F., and 12 others, 2006, Slip zone and energetics of a large earthquake from the Taiwan Chelungpu-fault Drilling Project: Nature, v. 444, p. 473-476, doi:10.1038/nature05253.

Marone, C., Saffer, D.M., McKiernan, A., Rowe, C.D., and Samuelson, J., 2005, Friction constitutive properties of fault zone materials: Eos (Transactions, American Geophysical Union), v. 86, Fall Meeting Supplement, Abstract S32B-05.

Mastalerz, M., Wilks, K.R., Bustin, R.M., and Ross, J.V., 1993, The effect of temperature, pressure and strain on carbonization in high-volatile bituminous and anthracitic coals: Organic Geochemistry, v. 20, p. 315-325, doi:10.1016/0146 -6380(93)90047-F.

Meneghini, F., Di Toro, G., Rowe, C.D., Moore, J.C., Tsutsumi, A., and Yamaguchi, A., 2010, Record of mega-earthquakes in subduction thrusts: The black fault rocks of Pasagshak Point (Kodiak Island, Alaska): Geological Society of America Bulletin, v. 122, p. 1280-1297, doi:10.1130 /B30049.1.

O’Hara, K., 2001, A pseudotachylyte geothermometer: Journal of Structural Geology, v. 23, p. 1345 1357, doi:10.1016/S0191-8141(01)00008-6.

Peters, K.E., Walters, C.C., and Moldowan, J.M., 2005, The Biomarker Guide, $2^{\text {nd }}$ ed.: Cambridge, UK, Cambridge University Press, $492 \mathrm{p}$.

Pittarello, L., Di Toro, G., Bizzarri, A., Pennacchioni, G., Hadizadeh, J., and Cocco, M., 2008, Energy partitioning during seismic slip in pseudotachylyte-bearing faults (Gole Larghe Fault, Adamello, Italy): Earth and Planetary Science Letters, v. 269, p. 131-139, doi:10.1016/j.eps1 2008.01.052

Polissar, P.J., Savage, H.M., and Brodsky, E.E., 2011, Extractable organic material in fault zones as a tool to investigate frictional stress: Earth and Planetary Science Letters, v. 311, p. 439-447, doi:10.1016/j.epsl.2011.09.004.

Reches, Z., and Dewers, T.A., 2005, Gouge formation by dynamic pulverization during earth- quake rupture: Earth and Planetary Science Letters, v. 235, p. 361-374, doi:10.1016/j.epsl .2005.04.009.

Rowe, C., Moore, J., Meneghini, F., and McKiernan, A., 2005, Large-scale pseudotachylytes and fluidized cataclasites from an ancient subduction thrust fault: Geology, v. 33, p. 937-940, doi:10.1130/G21856.1.

Rowe, C.D., Meneghini, F., and Moore, J.C., 2011, Textural record of the seismic cycle: Strain rate variation in an ancient subduction thrust, in Fagereng, Å., Toy, V.G., and Rowland, J.V., eds., Geology of the Earthquake Source: A Volume in Honour of Rick Sibson: Geological Society of London Special Publication 359, p. 77-95, doi:10.1144/SP359.5.

Sakaguchi, A., Chester, F., Curewitz, D., Fabbri, O., Goldsby, D., Kimura, G., Li, C.-F., Maskai, Y., Screaton, E.J., Tsutsumi, A., Ujiie, K., and Yamaguchi, A., 2011, Seismic slip propagation to the updip end of plate boundary subduction interface faults: Vitrinite reflectance geothermometry on Integrated Ocean Drilling Program NanTro SEIZE cores: Geology, v. 39, p. 395-398, doi:10.1130/G31642.1.

Sibson, R.H., and Toy, V.G., 2006, The habitat of fault-generated pseudotachylyte: Presence vs. absence of friction-melt, in Abercrombie, R., McGarr, A., Di Toro, G., and Kanamori, H., eds., Earthquakes: Radiated Energy and the Physics of Faulting: American Geophysical Union Geophysical Monograph 170, p. 153-166.

Spray, J.G., 2010, Frictional melting processes in planetary materials: From hypervelocity impact to earthquakes: Annual Review of Earth and Planetary Sciences, v. 38, p. 221-254, doi:10.1146/annurev.earth.031208.100045.

Tilicheev, M.D., 1949, Kinetics of cracking of hydrocarbons under pressure: Foreign Petroleum Technology, v. 7, p. 209-224.

Tinti, E., Spudich, P., and Cocco, M., 2005, Earthquake fracture energy inferred from kinematic rupture models on extended faults: Journal of Geophysical Research, v. 110, B12303, doi: 10.1029/2005JB003644.

Tsutsumi, A., Rowe, C.D., Moore, J.C., Meneghini, F., and Yamaguchi, A., 2008, High velocity frictional properties of subducting materials: An example study for argillaceous melange rock, in Proceedings, Japan Geoscience Union Meeting, Abstract J163-002.

Voge, H.H., and Good, G.M., 1949, Thermal cracking of higher paraffins: Journal of the American Chemical Society, v. 71, p. 593-597, doi:10.1021/ja01170a059.

Vrolijk, P., Myers, G., and Moore, J.C., 1988, Warm fluid migration along tectonic melanges in the Kodiak Accretionary Complex, Alaska: Journal of Geophysical Research, v. 93, p. 10,31310,324, doi:10.1029/JB093iB09p10313.

Waples, D.W., 2000, The kinetics of in-reservoir oil destruction and gas formation: Constraints from experimental and empirical data, and from thermodynamics: Organic Geochemistry, v. 31, p. 553-575, doi:10.1016/S0146-6380(00)00023-1.

Wei, Z., Moldowan, J.M., Jarvie, D.M., and Hill, R., 2006, The fate of diamondoids in coals and sedimentary rocks: Geology, v. 34, p. 10131016, doi:10.1130/G22840A.1.

Manuscript received 2 July 2013

Revised manuscript received 24 September 2013

Manuscript accepted 2 October 2013

Printed in USA 